IZA DP No. 5008

Rising Wages:

Has China Lost Its Global Labor Advantage?

Dennis Tao Yang

Vivian Chen

Ryan Monarch

June 2010 


\title{
Rising Wages: Has China Lost Its Global Labor Advantage?
}

\author{
Dennis Tao Yang \\ Chinese University of Hong Kong \\ Vivian Chen \\ The Conference Board \\ Ryan Monarch \\ University of Michigan
}

\section{Discussion Paper No. 5008 \\ June 2010}

IZA

P.O. Box 7240

53072 Bonn

Germany

Phone: +49-228-3894-0

Fax: +49-228-3894-180

E-mail: iza@iza.org

\begin{abstract}
Any opinions expressed here are those of the author(s) and not those of IZA. Research published in this series may include views on policy, but the institute itself takes no institutional policy positions.

The Institute for the Study of Labor (IZA) in Bonn is a local and virtual international research center and a place of communication between science, politics and business. IZA is an independent nonprofit organization supported by Deutsche Post Foundation. The center is associated with the University of Bonn and offers a stimulating research environment through its international network, workshops and conferences, data service, project support, research visits and doctoral program. IZA engages in (i) original and internationally competitive research in all fields of labor economics, (ii) development of policy concepts, and (iii) dissemination of research results and concepts to the interested public.
\end{abstract}

IZA Discussion Papers often represent preliminary work and are circulated to encourage discussion. Citation of such a paper should account for its provisional character. A revised version may be available directly from the author. 


\begin{abstract}

\section{Rising Wages: Has China Lost Its Global Labor Advantage?*}

We document dramatic rising wages in China for the period 1978-2007 based on multiple sources of aggregate statistics. Although real wages increased seven-fold during the period, growth was uneven across ownership types, industries and regions. Since the late 1990s, the wages of state-owned enterprises have increased rapidly and wage disparities between skillintensive and labor-intensive industries have widened. Comparisons of international data show that China's manufacturing wage has already converged to that of Asian emerging markets, but China still enjoys enormous labor cost advantages over its neighboring developed economies. Our analysis suggests that China's wage growth will stabilize to a moderate pace in the near future.
\end{abstract}

JEL Classification: J31, J21, O5

Keywords: $\quad$ wage growth, aggregate statistics, China, international comparison

Corresponding author:

Dennis T. Yang

Department of Economics

Chinese University of Hong Kong

Shatin, N.T.

Hong Kong

E-mail: deyang@cuhk.edu.hk

\footnotetext{
* The authors are grateful to Judith Banister, Gail Fosler, David Hoffman, Tomoko Kishi, Bart Van Ark, Harry Wu, an anonymous referee and participants at the Western Economic Association International Pacific Rim Conference in Kyoto for helpful suggestions and comments on an earlier version of this paper. We would also like to thank Yuanfang Li, Xiaoqin Li, Huifang Liang, Thomas Mosk, Jessie Pang, Ke Shen and Ricky Sim for capable research assistance, including the construction of Chinese domestic and international data. Dennis Yang would like to acknowledge research support from the Center for China in the World Economy (CCWE) at Tsinghua University and the Institute of AsianPacific Studies at Chinese University of Hong Kong. He is also grateful to the CCK Foundation for International Scholarly Exchange for a research grant awarded to this project.
} 
Rising Wages: Has China Lost Its Global Labor Advantage?

\section{Introduction}

In the past decade, China's emergence as the workshop of the world and as the largest receiver of foreign direct investment (FDI) has profoundly influenced global trade patterns and the competitive landscape. The impetus for these successes stems in large part from China’s comparatively low wages for workers. However, Chinese wages have risen sharply with globalization; average real wages more than tripled in the ten years from 1997 to 2007, according to published government data. Since soaring wages may eventually erode one of China's most prominent global economic advantages, its low labor costs, this phenomenon has drawn increasing attention from social scientists, policy makers and the public. Two recent studies by Chinese academic institutions sound the alarm on issues concerning China's labor market conditions. The Institute of Population and Labor Economics at the Chinese Academy of Social Sciences (CASS), in its Green Book on Population and Labor 2007, predicted that China will reach a "Lewisian turning point," where rural surplus labor is depleted to such a level that continuing industrialization cannot be supported cheaply (Cai, 2007). Independently, the Development Research Center of the State Council, in a 2007 survey covering 2749 villages, also proclaimed that three-quarters of villages have no suitable young labor remaining to transfer from agriculture into other sectors. Both studies forecasted severe labor shortages and an acceleration of wage rises in China, starting as early as 2009 or 2010 .

Anxiety over rising labor costs in China has also spread to international advisory and business communities. Recent reports have warned that China is starting to lose its luster as a 
manufacturing base for exports. ${ }^{1}$ Similar dispatches note that since accelerated wage growth squeezes the margins of multinational corporations (MNCs), the conditions for FDI in China are deteriorating relative to other emerging economies in Asia. ${ }^{2}$ Yet, despite the prominence of such narratives, there remains little systematic documentation on the extent and scope of rising wages in China. There is also a dearth of reliable information on how wages in China compare with levels in other emerging and advanced economies.

This paper seeks to fill this gap by documenting systematically the changes in the structure of wages in China for the period 1978-2007 and by comparing China's wage levels with its neighboring Asian economies. Our analysis proceeds in three steps. First, we provide a careful analysis of China’s changing wage levels over time across major industries, ownership categories and geographic locations by compiling and adjusting aggregate statistics from many different published sources. We show that, though it is true that real wage has increased seven-fold in the past three decades, the growth has been uneven. Wages of state-owned enterprises (SOEs) have increased rapidly in the past decade, currently surpassing the level of the non-public sector, and wage disparities between skill-intensive and labor-intensive

\footnotetext{
1 An article in BusinessWeek (March 27, 2006) notes that corporations and suppliers are beginning to look for more profitable options, including countries such as Vietnam or Indonesia. The Economist (January 11, 2007) notes that pay for factory workers has been rising at “double-digit rates for several years.” The New York Times (August 29, 2007) profiles a number of factory managers having difficulty finding workers and dealing with wage rises.

${ }^{2}$ Rising labor costs has been one of the important reasons that forced thousands of small and medium manufacturing firms in Guangdong province to cease production, go bankrupt, or relocate to other regions with more desirable operating conditions in the past one to two years. Guangdong accounts for roughly one third of China's total export. The Economist (January 11, 2007) notes spiraling costs mean that firms are searching for better investments elsewhere in Asia, including Malaysia, Thailand, and Vietnam. The Japanese External Trade Organization has encouraged companies with a China-Plus-One Strategy to consider strengthening their policy towards the "Plus One” (JETRO, 2006).
} 
industries and between geographic regions in China, which began to appear in the 1990s, have widened considerably.

Secondly, we utilize data sources from the International Labor Organization (ILO) and the United Nations Industrial Development Organization (UNIDO) to construct internationally comparable time series of manufacturing wages of China and ten neighboring economies and regions in Asia. These two independent statistical sources complement each other by demonstrating consistent trends in cross-country wage comparisons, in ways that have not been attempted previously. Although China's manufacturing wage has grown faster than its neighbors, its wage level is only just beginning to be competitive with other developing countries in the region. China continues to enjoy enormous cost clout advantages over more developed economies, as its wage level is, on average, still only about 7 to $21 \%$ of economies such as Japan and Hong Kong.

Thirdly, we analyze the demand and supply conditions for skilled and unskilled labor in China covering the periods before and after the outbreak of the current economic crisis. Overall, our views are less pessimistic than the studies discussed earlier: wage growth for unskilled labor will be moderate due to the potentially large supply of workers, made up of workers from the rural sector and employees who were laid off as a result of state-sector restructuring. Wage growth for skilled labor will also likely taper off because of the convergence of college wage premiums to international standards in recent years and the anticipated robust supply of university graduates and returned professionals from overseas. We conclude that China will still maintain its competitive edge in low labor cost in the near future. 
The paper proceeds as follows. Section 2 analyzes wage trends within China, while Section 3 consolidates international data and compares China's manufacturing wage levels with its Asian neighbors. Section 4 presents a demand and supply analysis of China's markets for skilled and unskilled labor, shedding light on the likely development of wage trends in the near future. Section 5 concludes with a brief assessment of the impact of current economic crisis on unemployment and wages in China.

\section{Changes in China’s Wage Structures, 1978-2007}

\section{A. Data and Related Literature}

Profound socioeconomic transformations, including massive privatization, industrial structural changes and regional development, have occurred in China since the inception of reforms in 1978. China’s wage structures have evolved accordingly, exhibiting major changes across ownership categories, industries and regions over three decades. These changes have implications for both its domestic economy and international competitive landscape. In analyses of the world's largest manufacturing workforce, Banister (2005) and Lett and Banister (2006) estimate China's manufacturing earnings and compensation for the period 2002-2004, based on published data from various editions of the China Labor Statistical Yearbook and the China Village and Town Enterprise Yearbook. To gauge time trends in manufacturing earnings, Banister (2005) presents earnings of staff and workers for the manufacturing sector covering the period 1990-2002. They also assess the quality of China's statistics on manufacturing earnings, and for 2002, with estimates available for both the urban and rural labor force, they compare China's manufacturing compensation with wages levels observed for the newly industrialized economies in Asia and several other 
developing and developed economies and regions. To our knowledge, these are the only papers that systematically document aggregate wage trends in China; even these, however, have coverage limited to the manufacturing sector and to selected years and periods.

The recent burgeoning literature on income inequality and labor markets has explored the determination of labor earnings during transition, with an emphasis on microeconomic economic behavior for selected years. Two widely used household data sets are the China Household Income Project (CHIP) and the Urban Household Survey (UHS) - the former has three waves of surveys with data for 1988, 1995 and 2002, while UHS data covers annual cross-sectional information since the late 1980s. ${ }^{3}$ Economists have employed the data for studying topics such as returns to education (e.g., Liu, 1998; Li 2001; Fleisher et al. 2005; Zhang et. al. 2005; Yang, 2005), income inequality (e.g. Gustafsson et al. 2008), and the gender earning gap (e.g., Knight and Song 2003). Varying with individual projects, informative statistics on changes in wage levels and employment structures are presented for selected years and subgroups of the workforce, but there has been no documentation of broad changes in wage trends and employment structures. The paucity of studies on China's wage trends reflects in part the lack of systematic, consistent aggregate data that cover wages and labor compensation over a wide basis and an extended period of time.

This paper undertakes the task of constructing and presenting general patterns of urban real wages for China by provinces, by ownership types and by industries for the period 1978-2007, with a larger scope to the question than previous research. The paper concentrates

\footnotetext{
3 Although UHS is an annual survey running more than twenty years, due to various restrictions on data usage from the National Bureau of Statistics (NBS), researchers have only had access to UHS data for a limited number of provinces in selected years.
} 
its energies on the checking and integrating of various data sources, ensuring consistency of data reporting, and adjusting changes in variable definitions, resulting in a broad description of wage trends in China. More specifically, we rely primarily on several major published sources of aggregate statistics for China, including China Statistical Yearbooks, wage series from CEIC Data Company, Comprehensive Statistical Data and Materials on 55 Years of New China (NBSb, 2004) and the China Labor Statistical Yearbooks. Wage statistics, and information needed to compute the changes of real wages over time, such as consumer prices indices (CPI) and total employment numbers are scattered and inconsistently reported in these sources of China's aggregate statistical data. Our goal is to assemble all related information and construct a clean and unique set of wage data using China Statistical Yearbook, CEIC and 55 Years to mark the changing trends of wages across ownership types, geographic locations and major industries since the inception of the economic reform in 1978 up through 2007, the most recent year with available data. We have posted a not-for-publication data appendix, which includes data sources, definitions, adjustments made and original data tables, at http://www.cuhk.edu.hk/eco/staff/dyang/Data-Appendix.doc.

The wage and employment information used in the paper are based primarily on the Comprehensive Labor Statistics Reporting System of the NBS, which covers all independent accounting units and relies on complete enumeration and reporting from lower levels to higher levels of work units (NBSa, 2008). The term “work unit” denotes corporate enterprises and all non-enterprise units, such as government departments or administrative agencies, but excludes township enterprises, private units or self-employed business. The secondary data source is the Sample Survey on the Population Change, which contains information on the 
employment status and occupations of the population aged 16 and above for the whole country.

Wages in this paper refer to labor earnings for staff and workers (zhigong), which are “formal employment” comprising all laborers receiving payments and being employed by (a) state-owned units, (b) urban collectively owned units, (c) joint operation units, (d) limited liability companies and stock companies, (e) foreign-owned units, (f) units with investment from persons in Hong Kong, Macao, or Taiwan, or (g) units subordinate to one or more of the above units. ${ }^{4}$ Therefore, by definition, staff and workers are employed in cities, and they constitute more than 95\% of total employment in formal urban units over the selected years (Holz, 2006). Presumably they also include rural migrant workers employed in the (a)-(g) types of work units.

Total wages or earnings refer to the total remuneration payment to staff and workers during a period of a year (NBSa, 2008). They include all types of payments in money or in kind, including salaries paid for fixed time periods and other payments based on piece work, bonuses, allowances, subsidies, overtime pay, and extra pay for working under hazardous and dangerous conditions. Total wages are not equivalent to total labor compensation, a measure often used in international comparisons, which also includes pension contributions and social insurance payments that employers are required to pay to city governments on behalf of their employees or welfare fund payments such as employer contributions to housing funds, which

\footnotetext{
${ }^{4}$ Hence, the term staff and workers exclude persons (a) employed in township and village enterprises, (b) working in individual/private enterprises, (c) urban self-employed persons, (d) retirees, (e) re-employed retirees, (f) teachers working in informal schools, (g) foreigners and persons from Hong Kong, Macao and Taiwan who work in urban units, and (h) other persons not to be included by relevant regulations.
} 
are given to employees in the enterprises. We apply provincial level urban CPI to adjust nominal wage levels to real wages in 2007 Yuan $^{5}$.

\section{B. Wages by Ownership}

Between 1978 and 2007, the average real annual wage for staff and workers grew more than sevenfold from 3,285 to 24,932 Yuan, as Figure 1 shows. Influenced by three distinctive phases of reforms, wage growth exhibits systematic paths. Before 1985, the year considered as the beginning of major urban reforms, average wage growth was moderate, rising at a rate of 4.9\% per year. In the period 1986-1997, when employment in private, jointly-owned enterprises in other ownership categories experienced vigorous growth, nationwide wage growth was still at a modest rate of 3.9\%, which was influenced in part by two consecutive years of negative growth in 1988 and 1989 because of high inflation and political upheaval. In the period 1998-2007, wage growth accelerated to an astonishing 13.2\%. This period of wage explosion coincided with China's preparation for and accession into the WTO, as well as the major restructuring of SOEs that started in 1998.

A remarkable feature emerges from data trends documented in Figure 1. The average wage of SOEs, while lagging significantly behind that of the private sector-mostly consisting of domestic stock holding firms, joint ventures, and foreign firms—-throughout the 1990s, grew rapidly after 1998 and actually overtook those of private enterprises in 2003. Throughout the 1990s, the wage level in the private sector was on average $31 \%$ higher than state-sector wages. During this period, many talents were lured away from the state sector to

\footnotetext{
5 According to DataStream, in 2007, the average exchange rate was 7.452 Yuan (Chinese currency) to 1 U.S. Dollar. This is the nominal exchange rate we will use for international wage comparisons.
} 
work for joint ventures and foreign firms because of their superior labor compensation, a phenomenon known in China as “jumping into the sea.” But wages in the state sector began to increase sharply in the late 1990s, reaching 16,227 Yuan in 2003, surpassing private sector wages by a narrow margin for the first time since reform began. By 2007, the average wage in the state sector was about $11 \%$ higher than that of the private sector. Indeed, domestic Chinese firms have become more competitive, offering high wages to attract talents back from joint-venture and foreign firms. A new phrase- “coming back to shore”- has been coined to refer to the phenomenon that Chinese professionals working in joint-venture and foreign firms have felt strong incentives luring them to work for domestic companies.

State sector restructuring has underpinned the dramatic rise in state sector wages. Under China's planned economy, SOEs had low productivity, limited profits, high debt burdens and disguised unemployment, because of the SOE's important political function of maintaining low unemployment and ensuring social stability (see e.g. Dong and Putterman, 2003). The government set wages in SOEs based on a wage grid system that was dependent on seniority instead of performance. ${ }^{6}$ By the mid-1990s, the Chinese government realized that their gradualist reform policy could no longer manage the mounting losses of SOEs and decided to take more aggressive steps, first allowing the privatization of small and medium SOEs and then, beginning in 1997, moving forward with more aggressive restructuring. The objective was to shut down loss-making SOEs, establish modern forms of corporate governance, and de-link the provision of social services from individual employers. This would be

\footnotetext{
6 Administrative personnel were put into 20 salary grades, technicians and staff into 17 grades, and manual workers into 8 grades. Detailed wage tables explicitly set wage payments in each grade. There were minimum regional variations to adjust costs of living and variations across industries to reflect factors such as demand conditions. See Meng (2000) and Knight and Song (2003) for descriptions of wage systems under planning.
} 
accomplished through privatizing housing and shifting the federal responsibility of health insurance, unemployment insurance and pension provisions into the joint responsibilities of local governments, employers and employees themselves. These aggressive reforms led to mass layoffs in SOEs. From 1996 to 2002, about 40 million workers were laid off, including 32 million from the state sector. The massive exodus of the least efficient workers provided a burst of vitality to the state sector. Using industrial firm-level data, Deng et al. (2007) find that labor productivity at SOEs tripled from 1995 to 2003, with more than 34\% of productivity growth attributable to substantial job elimination. Substantial gains in productivity enabled the state sector to raise wages of their workers. ${ }^{7}$

However, restructuring has led to mounting unemployment among urban workers. Based on the 2001 China Urban Labor Survey and the 2000 Population Census, Giles et al. (2005) estimated that the unemployment rate of urban permanent residents increased from $6.1 \%$ in 1996 to $11.1 \%$ in 2002. Using independent population data sources, Knight and Xue (2006) have arrived at similar estimates that China’s urban unemployment rate increased gradually from $7.7 \%$ in 1995 to $11.5 \%$ in 2000 . Unemployment was widespread, hitting older workers, women and those with less education particularly hard (Giles et al. 2006). In later discussions, we will propose our view that these laid off workers constitute an effective segment of the labor supply pool of the unskilled workers, which presents the one possibility for the limiting of further increases in the wages of unskilled labor.

\footnotetext{
7 The monetarization of non-wage benefits is likely another force that contributed to rising wages in the state sector. Under planning, SOEs provided various non-wage benefits such as housing services, health care, work insurance and even child care for the children of their employees. With state sector restructuring, such benefits have been monetized, converting the implicit or shadow wages to explicit wages. Such processes have coincided with massive layoffs in SOEs, contributing to wage growth in China’s public sector (see Ge and Yang, 2009).
} 


\section{Wages by Region}

Three decades into the era of reform, the once-egalitarian distribution of wages across

China’s provinces has disappeared, replaced by significant variations in worker compensation that define the regional comparative advantage in labor costs within China itself. Recent literature has shown that regional equality declined in the initial phase of reform between 1978 and 1985, but inter-regional inequality has increased considerably since then (e.g., Yang, 2002; Kanbur and Zhang, 2005; Wan et al., 2007). While earlier studies have used per capita income or consumption expenditures as measures of inequality, with time coverage usually ending with China's entrance into the WTO in 2001, we present evidence of wage distributions across China's regions and provinces and update the coverage to 2007. Our measure of wage dispersions for workers, rather than consumption or per capita income, offer more direct information on inequality that also is relevant for the study of varying regional labor costs.

Figure 2 presents the real annual wage of staff and workers across six regions in China, ${ }^{8}$ showing diverging wage patterns. During the first decade of reform, the average wages of all regions were clustered; but by now, the Southeastern and Bohai regions have the highest average wages in the nation, surpassing the wage levels of four other regions by about

\footnotetext{
${ }^{8}$ Following NBS’s system of regional classifications, we group China's 30 provinces into six regions: Bohai (consisting of Beijing plus surrounding provinces), Southeast (including Shanghai, Guangdong and other coastal provinces), Northeast (representing several traditional industrial regions of China), Central, Southwest, and Northwest. Tibet is not grouped into any of the regions because it has a very short series of wage data and the sample size is very small. Regional wages are computed as weighted averages of provincial wages, where the weights are employment shares of staff and workers of the provinces within the regions. Our data appendix contains detailed descriptions of data and the complete tabulations of provincial and regional wages for the period 1978-2007 are available upon reader’s request.
} 
$30-40 \%$. The highest wage growth in the past twenty years has occurred in the in Southeastern and Bohai regions, coastal areas where the mega-cities of Beijing, Shanghai, Guangzhou and Shenzhen are located. The lopsided high wages in coastal regions and metropolises — along with fast wage growth across all regions since the late 1990s-lend data support to anecdotal evidence of rising wages and labor shortages described in recent media and government reports. Using two standard inequality measures, the GINI coefficient and coefficient of variation, Table 1 provides additional evidence on the extent of diverging labor earnings across provinces and regions in China. Overall, regional wage variations have increased persistently and significantly in the past three decades. Comparing average values of the two inequality indicators for the periods 1978-1985 and 2001-2007, wage inequality nearly doubled across provinces and almost tripled across regions. ${ }^{9}$ Today, large regional variations in labor earnings exist in China.

A series of government policies and strategies, including urban-specific fiscal and credit programs as well as development strategies tilted towards the growth of coastal regions, especially when combined with restrictions on factor mobility, has contributed to unbalanced regional growth (e.g., Yang, 2002). Moreover, as Demurger et al. (2002) argues, initial economic conditions, such as advantageous geographic factors and superior endowments in physical and human capital, also helped attract FDI and promoted trade in the coastal regions. By the end of 1990s, the Chinese government became keenly aware that imbalanced

\footnotetext{
9 The GINI coefficients reported in Table 1 are notably low relative to GINI coefficients of income estimated using individual or household data, which have grown over the past three decades. One reason is that wages as measured here tend to have less variation than income due to the exclusion of non-labor earnings. Another reason is that aggregate wage inequality measures across provinces and regions do not necessarily reflect wage inequality across individuals within the aggregate units.
} 
development could result in instability and other social problems. This led to the launch of the Western Development Strategy, which aimed to reduce the severe inequality between coastal and interior regions. Consistent with this policy objective, the four measures of inequality we track indeed stopped increasing in recent years; and in 2006 and 2007, most measures of inequality actually declined. This could be the beginning of more balanced regional development in China.

\section{Wages by Industry}

Similar to wage patterns across regions, there is a clear diverging trend in wage levels across industries. As Figure 3 shows, wages across industries stay clustered until the early 1990s, but then average wages for skill-intensive industries, such as banking and insurance and scientific research and polytechnic services, rocketed past the wage levels in labor-intensive industries of manufacturing, construction, whole sale and retail services. ${ }^{10}$ For instance, in 1990, the average wage in construction (5,729 Yuan) was only about 14\% higher than the average in banking and insurance (5,040 Yuan). However, by 2007, the latter (49,435 Yuan) was 2.6 times of the former (18,758 Yuan). Specifically for 2007, the industries that had the highest wages were Banking and Insurance (49,435 Yuan), Information \& Computer (49,225 Yuan) and Scientific Research (38,879 Yuan). These wage trends reflect the rise in rewards to skills (or education) during China's economic transition. Indeed, the rate of return to education in urban China has increased from only 3-4\% per year of schooling in the late 1980s to above 10\% in recent years (e.g., Yang, 2005; Zhang et al., 2005).

\footnotetext{
${ }^{10}$ While Figure 3 presents wage trends for manufacturing, construction and selected service industries, the Data Appendix reports additional wage information covering all 19 industries based on the industrial classification system of the NBS.
} 
We emphasize one important finding. Contrary to popular belief that manufacturing wages grew the fastest because of China's rapidly increasing volume of exports, wage growth in this sector has been below the national average. This is despite the fact that manufactured goods accounted for more than $90 \%$ of China's exports and attracted approximately $60 \%$ of FDI in recent years (NBSa, 2007, 2008). In fact, manufacturing wages have moved in lockstep with wages in construction and wholesale and retail services, which are largely non-tradable sectors of the economy. There is strong evidence that competitive labor markets for unskilled workers have developed across these basic production and service industries, so that the wages in these industries have moved jointly. The upward movements in wages have been limited because workers in these industries can be drawn from the large pool of rural, “floating” laborers in cities, a group which has encompassed 130-200 million people in recent years. Rises in the wages of skilled labor, especially those with high educational attainment working in advanced service industries, have been the major force behind China's dramatic increases in the general wage level. The following section will compare manufacturing wages in China with those in its neighboring economies in order to shed light on China's international labor cost competitiveness.

\section{International Wage Comparisons}

Despite its considerable importance, data related to comparable cross country wages are not easily available or usable, largely due to the obstacle of international wage data being subject to a patchwork of definitions and coverage, all typically unique to individual country standards. The ILO October Inquiry labor market statistics for manufacturing are the most widely used data source in international wage studies (ILO, 2009). Based on this source, 
Freeman and Oostendorp (2000) transform wage information into a consistent data file for 161 occupations in over 150 countries from 1983 to 1998 and examine the pattern of pay across occupations and countries. While researchers have studied the effect of globalization and openness on wages (e.g., Freeman et al., 2001; Majid, 2004), their coverage is typically only up to late 1990s and their focus is not on China's comparative labor costs relative to other economies. Most closely related to our work is Adams et al. (2006), who compare China’s manufacturing wages as an important factor of global competitiveness with several neighboring economies, covering the period 1992 to 2001. Their findings corroborate the evidence reported by Lett and Banister (2006) that, in 2004, China’s average hourly manufacturing compensation of $\$ 0.67$ was only $2.9 \%$ that of the U.S. and far below that of other Asian newly industrialized economies. ${ }^{11}$

Instead of conducting wage comparisons for sporadic years, we take a comprehensive approach to the question by compiling and transforming original ILO data into comparable manufacturing wage series covering the period 1979 to 2007 for China and its Asian neighbors. In addition, we include a second data source, the UNIDO dataset, for making comparisons of manufacturing labor earnings (UNIDO, 2007). The UNIDO data has never been used to study China’s labor cost conditions, because China was not included in the sample. Recently, however, Wu and Yue (2008) have applied standard definitions of labor earnings comparable to those used by ILO and UNIDO and estimated manufacturing wages for China. We incorporate their newly available findings into the standard UNIDO data set

11 Chen et al. (forthcoming) and Ceglowski and Golub (2007) represent another string of studies that use the measure of unit labor costs (ULC) for assessing China's global labor competitiveness. 
covering the period 1981 to $2004,{ }^{12}$ thus enabling us to check the robustness of the comparative wage studies based on two alternative data series. In total, our study comprises six developing economies_-China, India, Indonesia, Malaysia, the Philippines and Thailand, as well as five developed economies_-Hong Kong, Japan, Korea, Singapore and Taiwan.

Comparable time series of manufacturing wages are constructed through two steps: first, we use country specific CPI with 2007 as the base year to obtain the real wage in local currency over time; then, we use 2007 exchange rates to the U.S. dollar to standardize different currencies. This approach has the advantage of capturing price trends within individual countries, thus enabling over-time wage comparisons across countries in a single currency. Monthly earnings per worker are used as the measure of wages, and similar to Chinese statistics, we use earnings and wages interchangeably. As defined in ILO LABORSTA Internet Yearly Statistics, earnings "relate to remuneration in cash and in kind paid to employees, as a rule at regular intervals, for time worked or work done together with remuneration for time not worked, such as for annual vacation, other paid leave or holidays.” Thus, earnings exclude employers' contributions to social security, pension schemes, and also exclude severance and termination pay. The UNIDO definition of earnings is similar to that of the ILO; see the Data Appendix for details of constructing and adjusting for comparable cross-country wages.

Beginning with the ILO comparisons, Figure 4A shows that the manufacturing wage in China was well below other selected developing economies in Asia in the 1980s, but because of the strong growth since the late 1990s, the gaps are largely closed. By 2007,

\footnotetext{
12 The 2005 UNIDO statistics are the latest available data because of its three-year lag data availability policy.
} 
China's manufacturing wages was comparable to the levels of the Philippines and Thailand, although still significantly below that of Malaysia. Figure 4B indicates that even though the manufacturing wage in China has increased at a fast clip over the past three decades, there remains an enormous gap between manufacturing wages in China and those in developed economies. In 2007, China’s manufacturing wage was about 7\% of Japan, 8-9\% of Korea and Singapore, and 18-21\% of Taiwan and Hong Kong (see Table 2). These results are clear evidence of the fact that China's wages have remained comparatively low and have not priced China out of its global advantages as the world's workshop and FDI magnet.

Our investigations based on the UNIDO statistical source carried out independently from the ILO data series lead to the same conclusion. Although wage levels implied by UNIDO data do not necessarily match with the ILO series, due in part to the differences in data collection methods, Figure 4 reveals that the overall picture remains the same. While fast earnings growth has already propelled manufacturing wages in China above those of Indonesia and India in the late 1990s, it still trails behind that of Malaysia and Thailand, and stays significantly below the levels in Hong Kong, Korea, Singapore and Japan. Indeed, the large percentage wage rises in China over the past one and half decades are essentially matched in absolute terms by wage rises in developed Asian economies or regions (see Table 2).

The wage comparisons presented so far have not taken into account the influence of recent currency appreciation of the Chinese Yuan on labor market competitiveness and the potential consequences of China's explosive growth in foreign exchange reserves. ${ }^{13}$ Between

\footnotetext{
${ }^{13}$ We thank the referee for directing our attention to the effect of exchange rate fluctuations on labor market
} 
June 2005 (when the strict dollar peg was abandoned) and July 2008, the Chinese Yuan appreciated by nearly 15\% against the US dollar, and since then the exchange rate has fluctuated around a narrow range of 6.83 to 6.85 Yuan to 1 US dollar; ceteris paribus, China's labor costs in US dollar-denominated accounts rose accordingly. Parallel to currency appreciation, China’s foreign exchange reserves began to grow at a significant pace starting from 2000 and the accumulation accelerated in more recent years. By March 2009, China’s foreign reserves topped 1.95 trillion US dollars, the largest among all countries in the world. It is widely believed that the Chinese Yuan will appreciate further if the central bank of China relaxes its control over the determination of exchange rates.

To incorporate the effect of exchange rate fluctuations, we also adopt a second approach in making international wage comparisons. First, we use year-by-year exchange rates of local currencies to convert manufacturing wages of individual countries into US dollars (indexed annually). Then, we deflate the wage series by consumer price index (CPI) of the US, using 2007 as the reference year, putting the data in comparable terms. Therefore, this alternative wage measure takes into account the changes in exchange rate of individual countries as well as the price trends of the US economy. This approach reflects the perspective of a US multinational business, or other companies using dollar-denominated accounts, who care about year-by-year wage calculations of labor costs in China and other economies. The results of the calculations based on both ILO and UNIDO data, which are broadly consistent with those found for the same countries covered in Figures 4 and 5, are reported in Figures A1 and A2 of the Data Appendix. The figures show that the long-term wage trends across 
countries are very similar to the patterns revealed in Figures 4 and 5, and all major conclusions continue to hold, although there are notably year-over-year variations in manufacturing wages due to exchange rate shifts, including the effects of severe currency depreciation in several economies during the Asian Financial Crisis in the late 1990s. While it is difficult to forecast whether China will reduce its control over the exchange rate of Yuan given added pressure for policy shifts stemming from growth in foreign reserves, existing evidence suggests that potential currency appreciation in the next several years is unlikely to alter the major conclusions we have drawn on China’s labor market competitiveness.

Therefore, two different data sources with two alternative data measures both underline the fact that the rising wage trend in China, while significant, belies no implication that its advantage as a major supplier of low cost labor will be displaced soon. The next section assesses the reasons driving the different spreads between skilled and unskilled labor, and outlines a framework for assessing the likely development of wage trends in China, determined by fundamental demand and supply forces in the labor market.

\section{Will China Maintain its Labor Cost Advantage?}

The wages trends analyzed above have captured the major features of China's evolving wage structures up to 2008, before the world economy plunged into the still deepening financial and economic crisis. Essentially, both cross-country manufacturing wage comparisons and the analysis of domestic labor earnings convey the same message: although there have been wage increases across the board, there is a clear difference between increases in the skilled and those in unskilled sectors. While wages for skilled labor increased sharply, wages for unskilled labor in manufacturing, construction and basic service sectors are still low, 
compared with both skill intensive sectors in China and wages in other developed Asian economies. This finding partly addresses some of the concern over China potentially losing its competitive edge due to its fast wage growth in recent years. Indeed, it is the sharp increase in the wages of skilled labor and the increasing share of the skilled labor in the total labor force that is the main thrust behind the overall wage rise pattern in China. Below we present some analyses of this wage growth disparity in skilled and unskilled labor, and argue that due to major shifts in demand and supply conditions in the labor market, the pace of rising wages for both skilled and unskilled labor is likely to slow down in the foreseeable future.

Strong demand for labor stemmed from the unprecedented GDP growth of more $10 \%$ per annum, and export growth of nearly 30\% per annum since China’s WTO accession in 2001 has been the major force pushing up the wage of workers with low skills. However, with exports and GDP growth likely cooling down to more sustainable levels, the demand for labor will lessen accordingly. Moreover, despite China’s remarkable export growth in manufactured goods, total employment in manufacturing has only increased modestly at an annual rate of about $3 \%$ in recent years (NBSa, 2008). Since the manufacturing sector employs predominantly workers with low education, its moderate pace of growing demand, perhaps neutralized by improved productivity coming from continued enterprise privatization and intense global competition, is not putting on additional pressure on labor demand.

With anticipated moderate demand for unskilled labor, the supply situation does not appear as depressing at all as what anecdotal evidence seems to suggest. Even though only one-fourth of the villages surveyed by the Development Research Council reported having 
young workers who can be transferred out of agriculture, this remaining population is still, in absolute terms, a huge untapped labor pool. According to Cai (2007), there are 490 million rural laborers in China, of which close to 200 million are employed in non-agricultural work. With current agricultural production technology, 180 million rural laborers are needed to maintain current level of agriculture output. Hence, there are about 110 million idle rural laborers with about 58 million under the age of 40 . This represents a viable segment of the population left to shift into non-agricultural work, one sign that there is no imminent threat of a supply crunch in unskilled labor.

Furthermore, during the economic restructuring period from 1996 to 2002, there were about 40 million workers who lost their jobs, as detailed above. Most of these unemployed workers are middle aged, but remain potentially productive. According to statistics published by Beijing Statistical Bureau, 38\% of the city’s 3.84 million unemployed in 2000 were between the ages of 35 to 44, making it the single largest age group among Beijing's unemployed. That percentage increased to 40 in 2002 according to China News (July 24, 2003). Thus, with unemployment rates hovering at double digits in many Chinese cities after the era of state-sector restructuring (Giles et al., 2005; Knight and Xue, 2006), mid-aged unemployed workers form another potential supply of unskilled labor, over and above the estimated 58 million young idle rural laborers. It is well known in China that an overwhelming majority of the employers impose an age requirement of 35 and below for job hiring. As wage rises further, these age prejudices are likely to be relaxed, and there will be more active participation responses from those laid-off workers. Thus, the supply of unskilled 
labor will not be in danger of any severe shortages, implying a strong likelihood for wages in the corresponding sectors to remain competitive.

While wage growth in labor intensive industries is likely moderated by smooth demand and an ample supply of unskilled labor, will the wage of skilled workers continue the steep climb? We believe that the sharp increases in the returns to skill will likely taper off in the near future because of two reasons. First, the rate of return to education, which has been tripled in the past two decades, has already reached the conventional levels observed in other market economies. As a legacy from central planning, low returns to schooling persisted for more than a decade since the inception of reform in late 1970s. However, beginning in the early 1990s, a set of major factors—including capital accumulation, labor market competition, inflow of FDI, export growth, state-sector restructuring, and skill-biased technological change-have increased general demand for skills (e.g., Zhao 2001; Ge and Yang, 2009). As a result, the estimated returns to education increased persistently, already exceeding $10 \%$ by the early 2000s (e.g., Zhang et al., 2005). In comparison, the average rate of return to another year of schooling is $9.7 \%$ for the world and $9.9 \%$ for Asia. ${ }^{14}$ As Chinese labor institutions approach completion of their transition to competitive markets, there will be limited scope for further increases in the returns to education.

Another major factor that prevents explosive growth in the wages of skilled labor is the large supply of college graduates over the past several years and those matriculating in the foreseeable future. Due to ever increasing demand for well educated workers and

\footnotetext{
14 George Psacharopoulos has published extensive summaries on rate of return to schooling estimates covering a wide variety of countries over time. The cited numbers are from his most recent global update, Psacharopoulos and Patrinos (2004); his earlier summaries were published in 1973, 1985 and 1994.
} 
professionals, the Chinese government decided to expand university enrollment in the late 1990s, resulting in a steep increase in the numbers of college graduates from 2001 and on. In 1998, the total number of admitted college students was approximately 1.08 million, a number that rose to 2.68 million in span of just three years. The year 2003 saw 1.88 million students graduating from universities, an increase of $40.4 \%$ from 2002, and 2.3 times the total number of graduates in 1998 (NBSa, 2004). According to the Ministry of Human Resources and Social Security (MHRSS), the number of new graduates reached a new record of 4.95 million in 2007—a 20\% increase from 2006 (MHRSS, 2008); and in 2008, total graduates increased again to 5.59 million. Despite well recognized problems such as aggressive increases in college enrollment potentially leading to significant declines in the quality of university education, especially among the newly expanded schools, and a college curriculum has long been criticized for its emphasis on memorization instead of practical skills, the sheer number of workers with college training will probably outweigh any other factors in applying downward pressure on college wage premiums.

Supplementary to domestic college graduates, another source of talent supply is returned overseas Chinese who often hold advanced degrees, have high level of English competence, and possess sought-after international work experience. Despite high demand for these talents, the number of returnees is still not overwhelming, with estimates varying from 140,000 to 275,000 (China Education Press, May 17, 2007). Recognizing the potential contributions that could be made by returnees, China's Ministry of Education has taken a number of actions to encourage overseas Chinese, especially scientists, engineers and executives, to return. Measures include a waiver of household registration, exemption from payroll quotas, flexible 
pay packages, and preferential access to jobs and schools for their family members. The government has also granted priority to the children and spouses of returnees in university admission and employment. The total number of overseas returnees has been on the rise in the past two to three years, a trend that should continue as economic conditions in North America and Europe continue to deteriorate. The inflow of professionals to China will help mitigate any upward pressure on wages, containing it within reasonable bounds.

\section{Concluding Remarks}

In this paper we have addressed the public concern over China's rapidly rising wages in recent years that are alleged to undermine China's global competitive labor advantage. Based on detailed data adjustments and careful construction, we have analyzed major changes in China's wage structures by ownership, region and industry for the period 1978-2007 and compared China's manufacturing wage level with neighboring Asian economies. Despite the dramatic overall wage growth in China, we find a persistently increasing gap between the wages in skill-intensive industries and labor-intensive industries, but we anticipate a robust supply of labor and skill will likely stabilize China's wage growth to a moderate pace in the near future. Compared with its neighboring economies, manufacturing wage in China remains only a small fraction of those in other developed Asian economies and has just started to approach other emerging markets. Therefore, China is likely to maintain a global labor advantage to support its status as the world's factory and remain an attractive destination for FDI.

This assessment of evolving wage structures can be viewed as directly applicable to China's labor market conditions up to the third quarter of 2008. The outbreak and subsequent deterioration in the financial and economic situation have caused fundamental changes to 
domestic labor markets and the international competitive landscape. Unemployment skyrocketed in all major economies, and there was enormous downward pressure on wages along with the collapse of energy prices. Concerns over rising wages in China and other emerging markets subsumed. The focus was entirely on the scenarios of anticipated horrific job losses.

It has become clear that the employment of unskilled labor in China, especially those rural migrants working temporarily in cities, took the heaviest blow. Signs of mass layoffs occurred in the second half of 2008. By October, according to estimates made by the Ministry of Human Resources and Social Security, 5.4\% of the 130 million rural migrants had already returned their homes in countryside because they lost their city jobs. Based on surveys conducted by the Ministry of Agriculture in 120 villages, 6.5\% rural migrants had returned home by the end of October 2008. According to NBS estimates, this rate rose to $10 \%$ by the end of 2008. One month later, 15.3\% of migrant workers, or 20 million, had lost their jobs, according to Chen Xiwen, director of the Office of the Central Leading Group on Rural Work. Using 782.4 million people as the economically active population in China in 2007 (NBSa, 2008), these newly lost jobs among migrants alone would push up the nationwide unemployment rate by $2.6 \%$. Lost jobs were heavily concentrated in export-oriented manufacturing and construction related businesses (Bottelier, 2009).

It appears that layoffs among high skilled urban workers have been rather limited. This is likely the outcome of the government's feverish attempts to control unemployment during this economic downtime, in fear that mass unemployment would lead to social instability. In the Document No. 4 issued by the State Council on February 3, 2009, China's central 
government placed job creation at the center of the current macroeconomic and structural adjustment policies. Detailed directives aiming at job creation included support for labor-intensive projects, favorable financing policies for small and medium size enterprises who could effectively absorb employment, provision of special incentives for hiring college graduates, and massive policy programs in forms of tax rebates, tax rate reductions, special loans, and reductions in social security submissions to secure the continued viability of enterprises and thus maintain a healthy demand for jobs. Moreover, a new regulation requires enterprises who plan to lay off 20 or more people or more than $10 \%$ of their labor force must inform the upper level labor unions 30 days prior to the action. In effect, this sets in an approval mechanism for all significant layoffs. Local governments have been mobilized to achieve re-employment targets and conduct training programs at deep discount rates for rural migrants and urban unemployed. All of these policies were carried out immediately.

The implementation of these policies has effectively eliminated any large scale layoffs in urban China. Understandably, the protection of employment positions has been at the expense of lowered salaries for existing employees, consistent with a survey report that $26 \%$ of workers in Beijing already experienced wage cuts due to the ongoing financial crisis (The Beijing News, January 6, 2009). Relative to flat-out unemployment, employment with reduced earnings is much less likely to cause social friction. The layoffs of rural migrants are not likely to cause severe social conflicts either, because those who lost their jobs have a safety net: namely returning to their rural homes. Rural land in China is not yet fully privatized. Returning home to participate in farm production or to find a local non-farm job may serve as a buffer to diffuse the fallout from urban unemployment. The much improved 
rural environment, supported in part by the elimination of agricultural taxation in 2006 and dramatic increases in rural investments in 2008, have led to major improvements in the quality of living in rural China.

Interventionist policies, however, will unavoidably create inefficiencies in the economic system. A remarkable achievement of China through the past decade is that globalization, market competition and state-sector restructuring have dramatically enhanced the labor productivity of all domestic enterprises in both state and non-state sector. Unfortunately, the ongoing interventions of the government to protect employment are reversing the achievements of increasing labor productivity and optimizing labor allocation. When output declines with the unfolding of the economic crisis, the existence of disguised unemployment in both the rural and urban sectors will no doubt lower China’s overall labor productivity and international competitiveness. Restoring the efficiency of labor allocation will be a challenging task facing China both for now and in years after the ongoing economic crisis, and that process will play an important role in determining China's future global labor advantage. 


\section{References}

Adams, F. Gerard, Byron Gangnes and Yochanan Shachmarove (2006) 'Why is China so Competitive? Measuring and Explaining China's Competitiveness', The World Economy 29 (2), 95-122.

Banister, Judith (2005) 'Manufacturing Earnings and Compensation in China', Monthly Labor Review 128 (8), 22-40.

Bottelier, Pieter (2009) 'China’s Economic Downturn: Employment is The Critical Issue', The Jamestown Foundation - China Brief Volume: 9 (3), 1-6.

Cai, Fang (ed.) (2007) Green Book of Population and Labor: The Coming Lewisian Turning Point and Its Implications. Beijing: Social Sciences Academic Press.

Ceglowski, Janet and Stephen Golub (2007) ‘Just How Low Are China’s Labor Costs?’ The World Economy 30, 597-617.

Chen, W. Vivian, Harry X. Wu, and Bart Van Ark (forthcoming) 'More Costly or More Productive? - Measuring Changes in Competitiveness in Manufacturing across Regions in China', Review of Income and Wealth

Demurger, Sylvie, Jeffrey Sachs, Wing Thye Woo, Shuming Bao, and Gene Chang (2002) 'Geogrophy, Economic Policy, and Regional Development in China', Asian Economic Papers 1 (1), 146-205.

Deng, Haiyan, John Haltiwanger, Robert McGuckin (2007) 'The Contribution of Restructuring and Reallocation to China's Productivity’, Working Paper \# 07-04, The Conference Board.

Dong, Xiaoyuan and Luis Putterman (2003) 'Soft Budget Constraints, Social Burdens, and Labor Redundancy in China’s State Industry’, Journal of Comparative Economics 31 (1), 111-128.

Fleisher, Belton, Klara Sabiriannova and Xiaojun Wang (2005) 'Returns to skills and the speed of reforms: Evidence from Central and Eastern Europe, China, and Russia’, Journal of Comparative Economics 33, 351-370.

Freeman, Richard B. and Remco H. Oostendorp (2000) 'Wages around the World: Pay Across Occupations and Countries' Working Paper 8058, National Bureau of Economic Research.

Freeman, Richard B., Remco H. Oostendorp and Martin Rama (2001) Globalization and Wages. Washington, DC: World Bank Press. 
Ge, Suqin and Dennis T. Yang (2009) 'Accounting for Rising Wages in China’, Manuscript, Department of Economics, The Chinese University of Hong Kong.

Giles, John, Albert Park and Juwei Zhang (2005) 'What Is China’s True Unemployment Rate?’ China Economic Review 16, 149-170.

Giles, John, Albert Park and Fang Cai (2006) 'How has Economic Restructuring Affected China’s Urban Workers?’ The China Quarterly March (185), 61-95.

Gustafsson, Bjorn A., Shi Li and Terry Sicular, editors (2008) Inequality and Public Policy in China, Cambridge: Cambridge University Press.

Holz, Carsten A. (2006) Measuring China’s Productivity Growth, 1952-2005, Manuscript, Social Science Division, Hong Kong University of Science and Technology.

ILO, International Labor Organization (2009) LABORSTA Data Base (http://laborsta.ilo.org).

JETRO, Japanese External Trade Organization (2006) JETRO White Paper 2006:

Conclusion-Japanese Companies Seek Growth in East Asia's Developing Integration.

Kanbur, Ravi and Xiaobo Zhang (2005) 'Fifty Years of Regional Inequality in China: A Journey through Central Planning, Reform and Openness’, Review of Development Economics 9 (1), 87-106.

Knight, John and Lina Song (2003) 'Increasing Urban Wage Inequality in China', Economics of Transition 4, 597-619.

Knight, John and Jinjun Xue (2006) 'How High is Urban Unemployment in China?' Journal of Chinese Economic and Business Studies 4 (2), 91-107.

Lett, Erin and Judith Banister (2006) 'Labor Costs and Manufacturing Employees in China: An Update to 2003-04’, Monthly Labor Review 129 (11), 40-45.

Li, Haizheng (2003) 'Economic Transition and Returns to Education in China', Economics of Education Review 22, 317-328.

Liu, Zhiqiang (1998) 'Earnings, Education, and Economic Reforms in Urban China', Economic Development and Cultural Change 46 (4), 697-725.

Majid, Nomaan (2004) 'What Is the Effect of Trade Openness on Wages?’ Employment Strategy Paper 18. Geneva: International Labor Organization.

Meng, Xin (2000) Labor Market Reform in China. New York: Cambridge University Press. 
MHRSS, Ministry of Human Resources and Social Security (various years) China Labor Statistical Yearbook. Beijing: China Statistics Press.

NBSa, National Bureau of Statistics of China (various years) China Statistical Yearbook. Beijing: China Statistics Press.

NBSb, National Bureau of Statistics of China (2004) Comprehensive Statistical Data and Materials on 55 Years of New China. Beijing: China Statistics Press.

Psacharopoulos, George, Harry A. Patrinos (2004). 'Returns to Investment in Education: A Further Update’, Education Economics 12 (2): 111-134.

UNIDO, United Nations Industrial Development Organization (2007) UNIDO Indstat4 2007: Industrial Statistics Database at the 4-digit Level of ISIC (Rev. 2 and 3).

Wan, Guanghua, Ming Lu and Zhao Chen (2007) 'Globalization and Regional Income Inequality: Empirical Evidence from within China’, Review of Income and Wealth 53(1), 35-59.

Wu, Harry X. and Ximing Yue (2008) 'Measuring Sectoral Labor Input in Chinese Industry, 1949-2005’, Manuscript, Department of Economics, Hong Kong Polytechnic University.

Yang, Dennis Tao (2002) 'What Has Caused Regional Inequality in China?' China Economic Review 13(4), 331-334.

Yang, Dennis Tao (2005) 'Determinants of Schooling Returns during Transition: Evidence from Chinese Cities', Journal of Comparative Economics 33, 244-264.

Zhang, Junsen, Yaohui Zhao, Albert Park and Xiaoqing Song (2005) 'Economic Returns to Schooling in Urban China, 1988 to 2001', Journal of Comparative Economics 33, 730-752.

Zhao, Yaohui (2001) 'Foreign Direct Investment and Relative Wages: The Case of China', China Economic Review 12, 40-57. 
Figure 1. Real Annual Wages of Staff and Workers by Ownership Type, 1978-2007

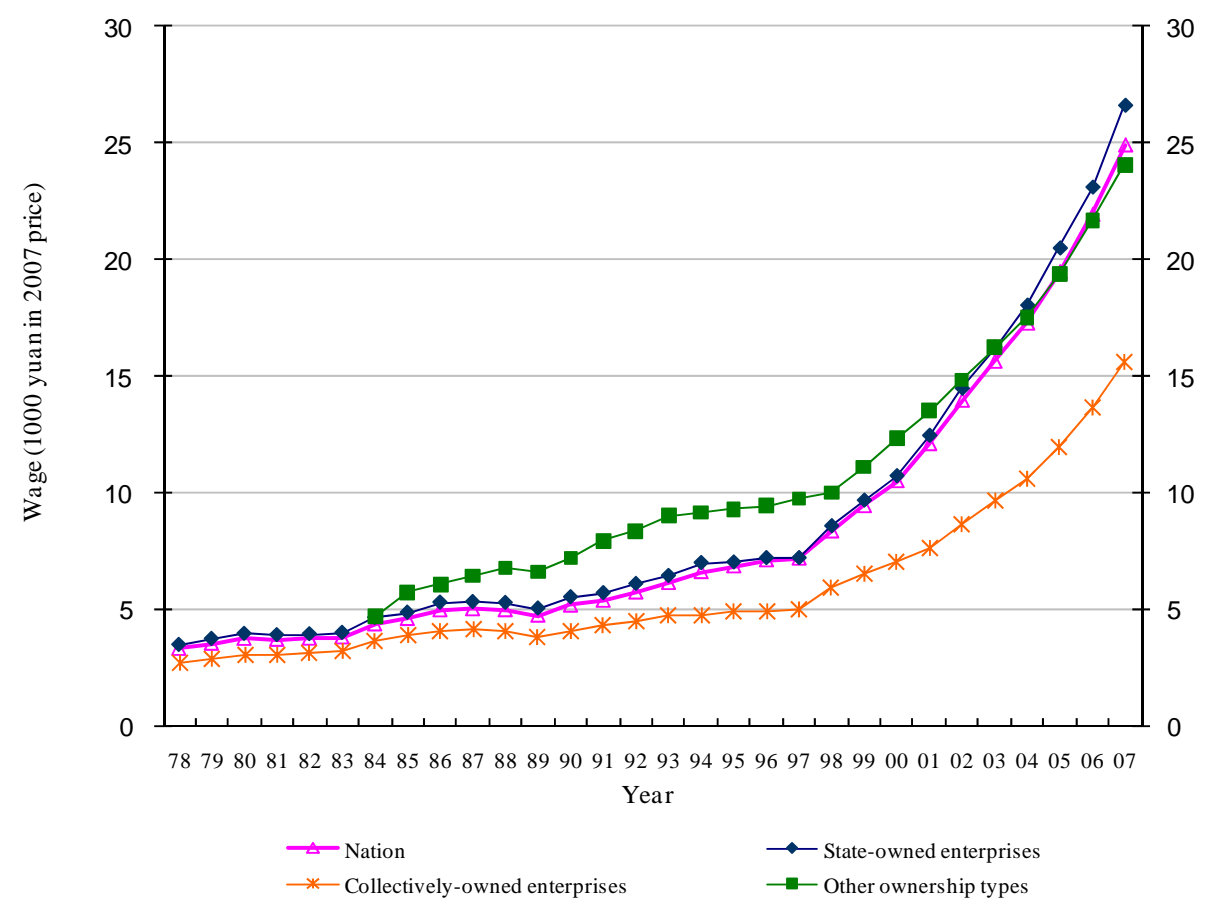

Figure 2. Real Annual Wages of Staff and Workers by Region, 1978-2007

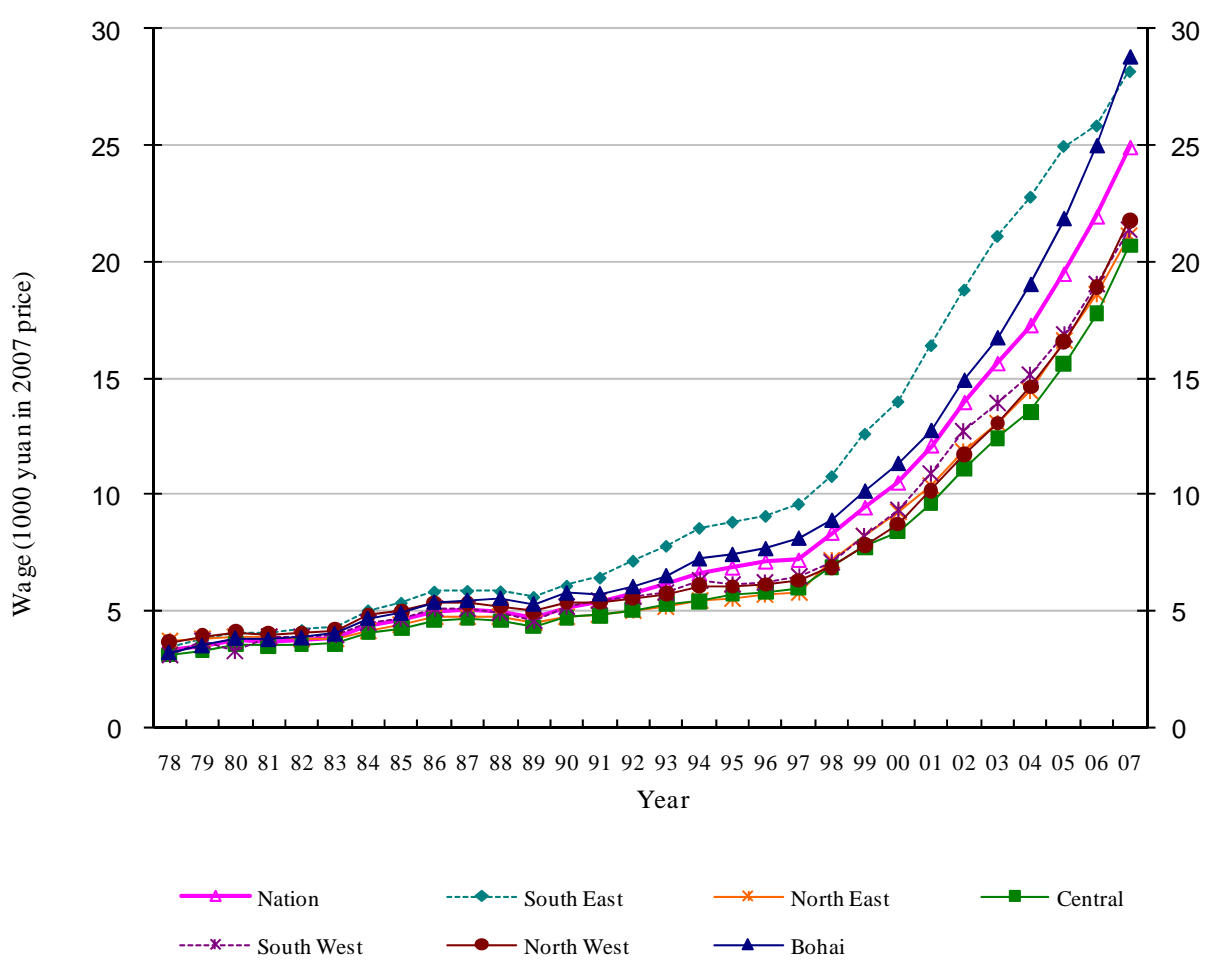


Figure 3. Real Annual Wages of Staff and Workers by Industry, 1978-2007

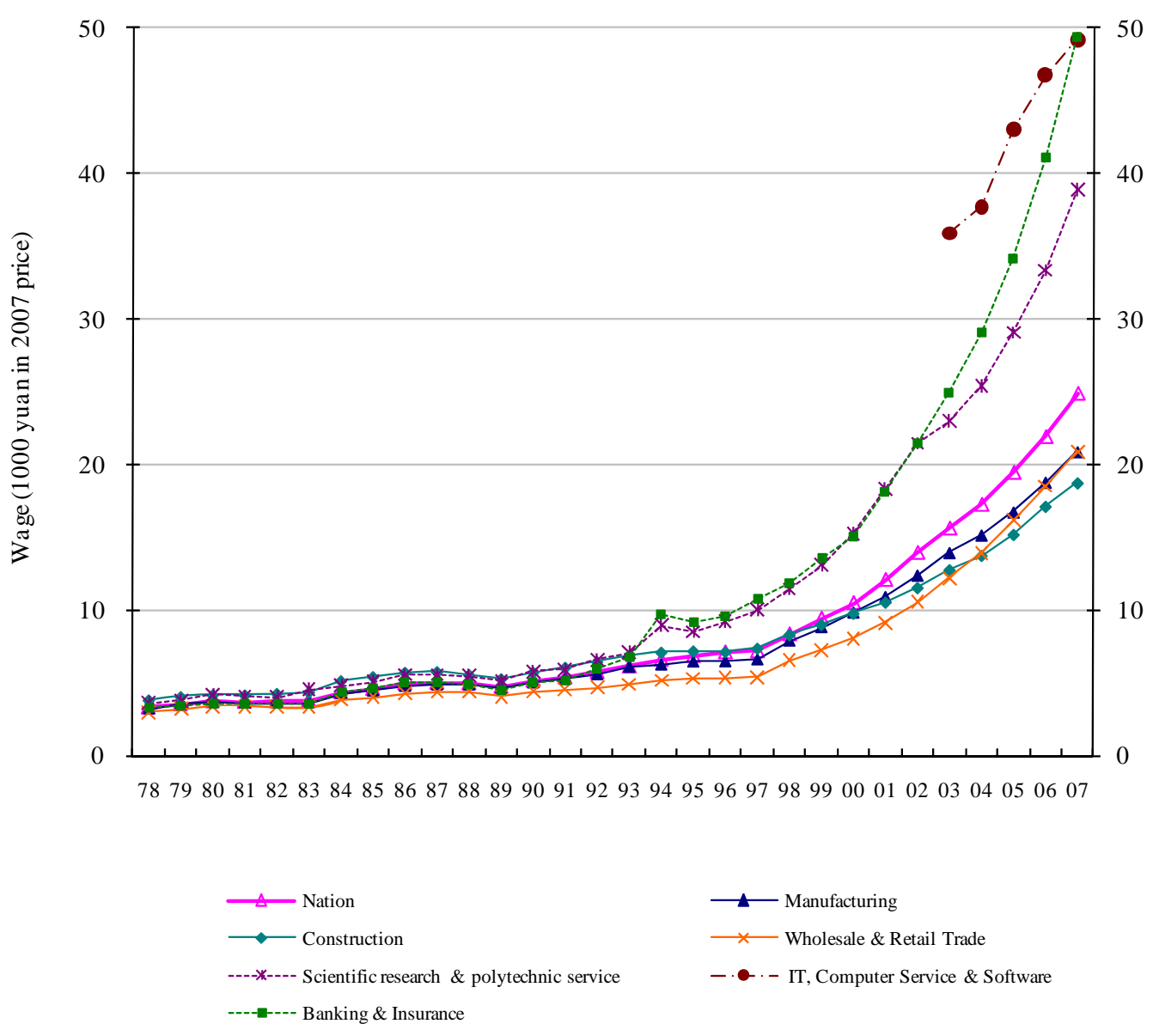


Figure 4. Comparison of Monthly Manufacturing Wages between China and Other Asian Economies, 1979-2007 (2007 US Dollars)

4.1. China and Other Emerging Economies

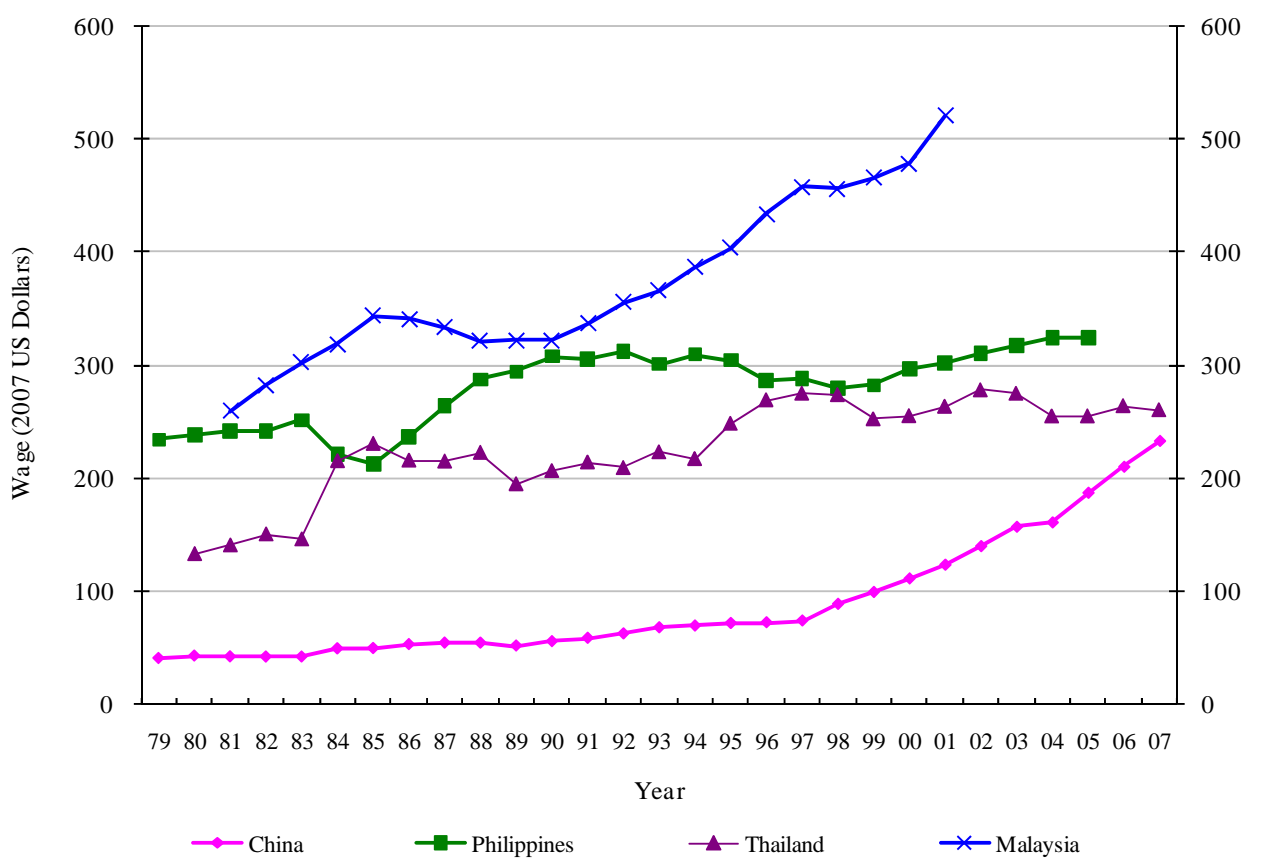

\subsection{China and Other Developed Economies}

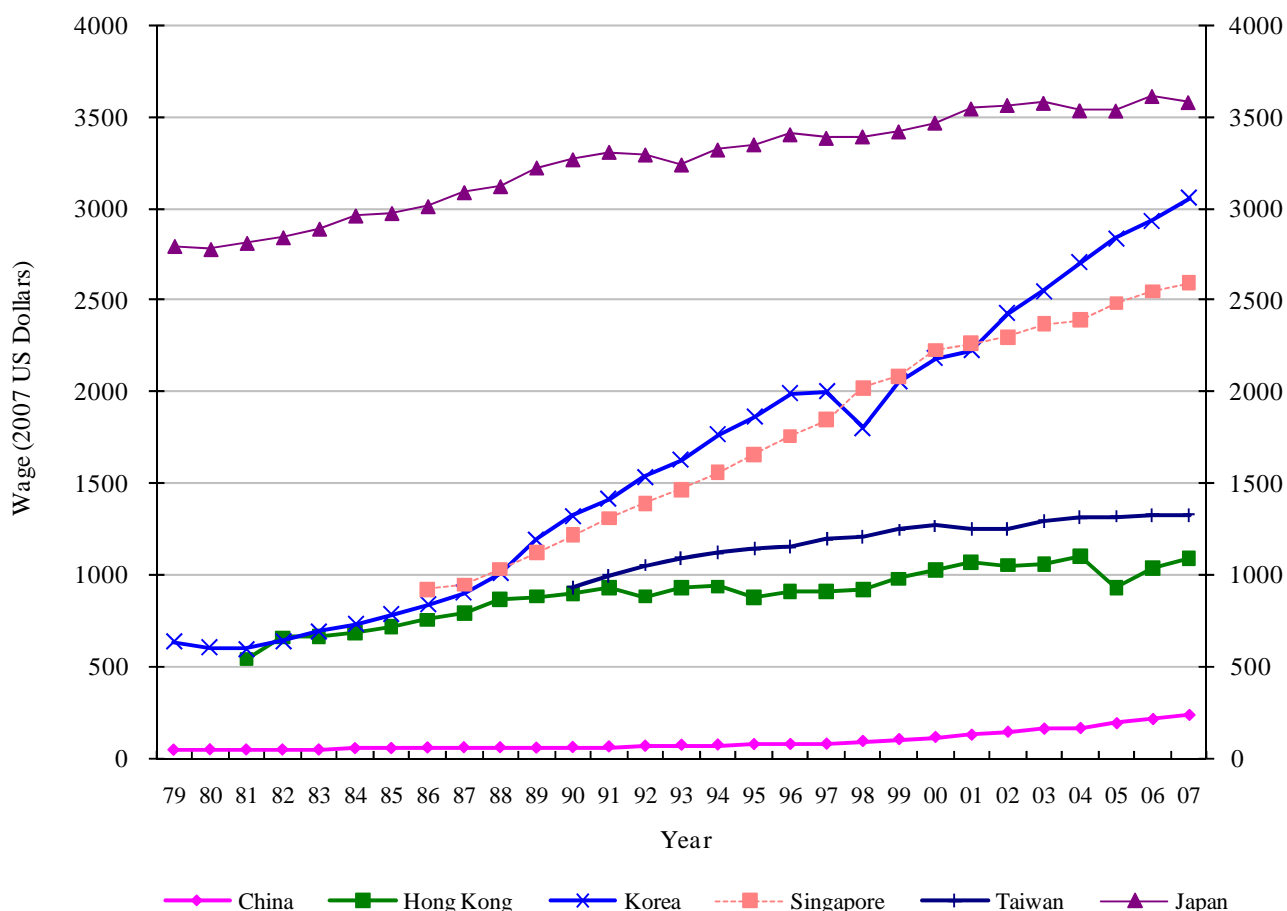

Data source: ILO (2009) 
Figure 5. Comparison of Monthly Manufacturing Wages between China and Other Asian Economies, 1981-2004 (2007 US Dollars)

5.1. China and Other Emerging Economies

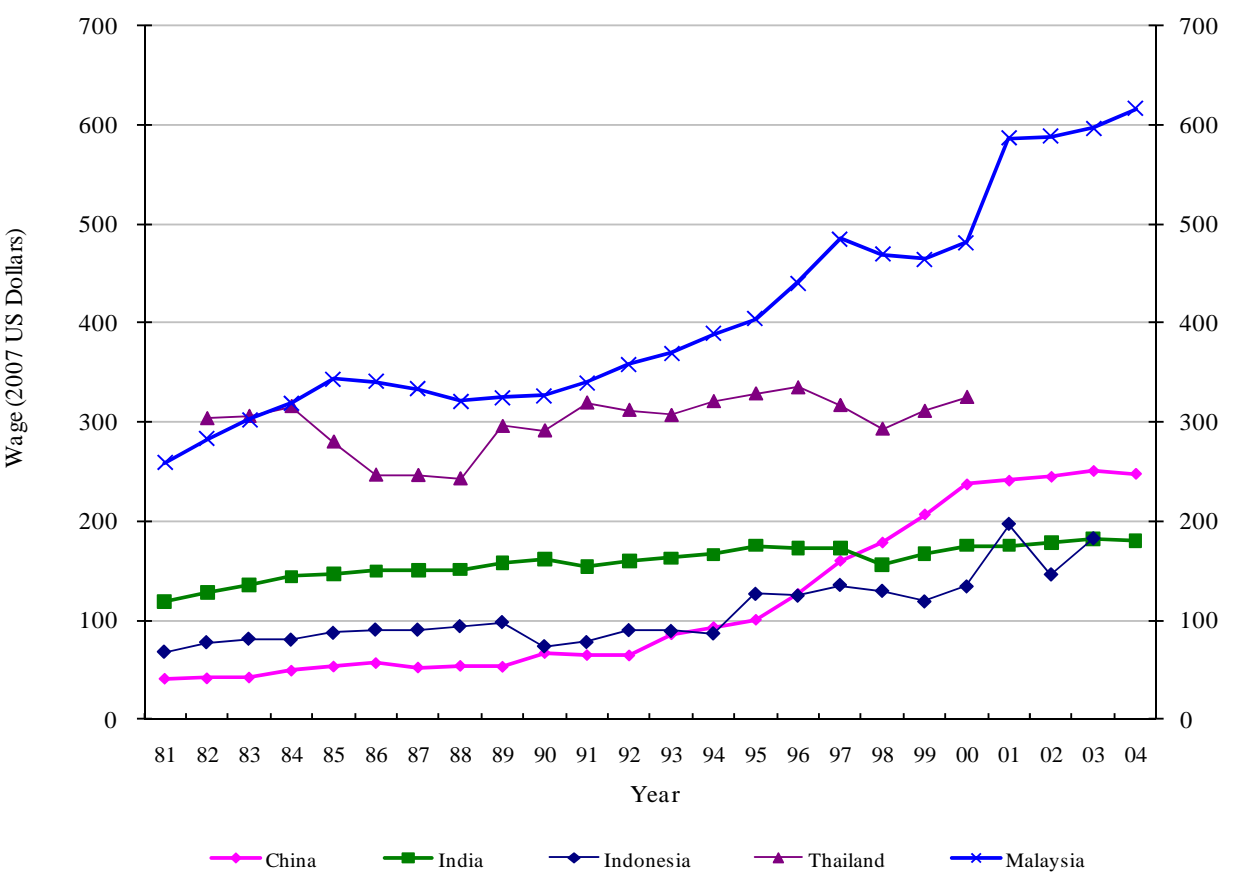

5.2. China and Other Developed Economies

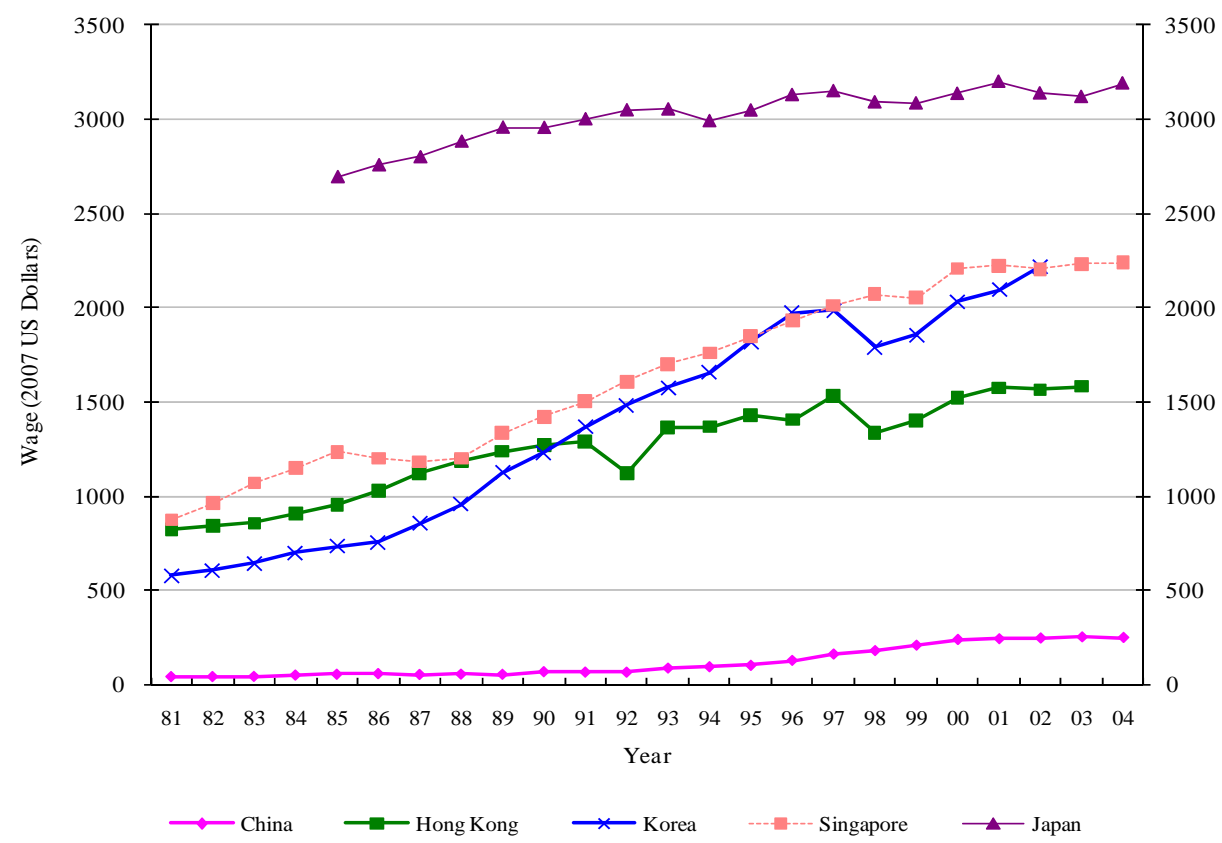

Data source: UNIDO (2008) and Wu and Yue (2008) 
Table 1. Wage Inequality across Provinces, Regions and Industries

\begin{tabular}{|c|c|c|c|c|c|c|}
\hline & \multicolumn{2}{|c|}{ Provinces } & \multicolumn{2}{|c|}{ Regions } & \multicolumn{2}{|c|}{ Industries } \\
\hline & GINI & $\mathrm{CV}$ & GINI & $\mathrm{CV}$ & GINI & $\mathrm{CV}$ \\
\hline 1978 & 8.6 & 16.3 & 4.8 & 7.9 & 10.3 & 18.1 \\
\hline 1979 & 8.5 & 15.9 & 3.4 & 5.8 & 10.4 & 18.3 \\
\hline 1980 & 7.5 & 14.6 & 4.7 & 7.9 & 9.7 & 17.2 \\
\hline 1981 & 7.5 & 14.5 & 2.9 & 5.0 & 9.5 & 16.9 \\
\hline 1982 & 7.7 & 14.9 & 3.4 & 5.6 & 9.3 & 16.7 \\
\hline 1983 & 8.6 & 17.3 & 4.0 & 6.4 & 10.1 & 17.6 \\
\hline 1984 & 9.1 & 18.1 & 5.2 & 8.4 & 10.0 & 17.8 \\
\hline 1985 & 9.1 & 18.1 & 5.4 & 8.7 & 8.8 & 15.2 \\
\hline 1986 & 8.8 & 17.2 & 5.3 & 8.7 & 8.1 & 14.0 \\
\hline 1987 & 9.1 & 17.8 & 5.4 & 8.7 & 8.1 & 13.9 \\
\hline 1988 & 9.5 & 18.1 & 5.9 & 9.6 & 5.9 & 11.0 \\
\hline 1989 & 10.1 & 19.1 & 6.3 & 10.3 & 7.1 & 12.6 \\
\hline 1990 & 9.3 & 17.6 & 6.5 & 10.6 & 7.7 & 13.6 \\
\hline 1991 & 9.2 & 17.2 & 6.8 & 11.3 & 8.1 & 14.1 \\
\hline 1992 & 9.7 & 19.1 & 8.1 & 13.9 & 7.8 & 14.3 \\
\hline 1993 & 10.9 & 21.6 & 9.3 & 16.3 & 9.2 & 16.9 \\
\hline 1994 & 12.7 & 24.1 & 11.1 & 18.9 & 11.7 & 20.4 \\
\hline 1995 & 12.3 & 24.5 & 11.0 & 19.5 & 11.2 & 19.6 \\
\hline 1996 & 12.8 & 25.8 & 11.2 & 19.8 & 11.7 & 20.3 \\
\hline 1997 & 13.6 & 27.3 & 12.1 & 21.3 & 12.9 & 22.2 \\
\hline 1998 & 13.9 & 28.0 & 10.8 & 19.9 & 12.5 & 21.7 \\
\hline 1999 & 13.8 & 28.7 & 11.5 & 21.1 & 13.3 & 22.9 \\
\hline 2000 & 14.2 & 28.5 & 11.8 & 21.1 & 13.9 & 23.8 \\
\hline 2001 & 14.7 & 29.1 & 12.0 & 21.7 & 14.9 & 25.4 \\
\hline 2002 & 14.1 & 27.9 & 12.1 & 21.5 & 15.4 & 26.3 \\
\hline 2003 & 14.3 & 29.1 & 12.3 & 22.2 & 18.3 & 34.6 \\
\hline 2004 & 14.0 & 29.1 & 12.2 & 21.6 & 18.5 & 34.1 \\
\hline 2005 & 13.8 & 29.4 & 11.2 & 20.2 & 19.1 & 35.3 \\
\hline 2006 & 14.0 & 30.2 & 9.5 & 17.1 & 19.6 & 35.8 \\
\hline 2007 & 13.4 & 30.0 & 8.8 & 15.9 & 19.9 & 36.1 \\
\hline 78-85 Avg. & 8.3 & 16.2 & 4.2 & 7.0 & 9.8 & 17.2 \\
\hline 86-90 Avg. & 9.4 & 17.9 & 5.9 & 9.6 & 7.4 & 13.0 \\
\hline 91-95 Avg. & 10.9 & 21.3 & 9.3 & 16.0 & 9.6 & 17.1 \\
\hline 96-00 Avg. & 13.6 & 27.6 & 11.5 & 20.7 & 12.9 & 22.2 \\
\hline 01-07 Avg. & 14.0 & 29.3 & 11.1 & 20.1 & 17.9 & 32.5 \\
\hline
\end{tabular}

Note: all figures in the table are percentages. 
Table 2: Comparison of Monthly Manufacturing Wages between China and Other Asian Economies (2007 USD)

\begin{tabular}{|c|c|c|c|c|c|c|c|c|c|}
\hline \multirow[b]{3}{*}{ Year } & \multicolumn{9}{|c|}{ A. ILO Wage Data } \\
\hline & \multicolumn{4}{|c|}{ Emerging markets } & \multicolumn{5}{|c|}{ Developed economies } \\
\hline & China & Malaysia & Philippines & Thailand & Hong Kong & Japan & Korea & Singapore & Taiwan \\
\hline 1980 & 42.6 & & 238.3 & 133.2 & & 2779.3 & 601.5 & & \\
\hline 1985 & 49.4 & 343.3 & 213.0 & 230.6 & 718.9 & 2976.9 & 784.5 & & \\
\hline 1990 & 55.4 & 322.5 & 307.6 & 206.6 & 900.5 & 3270.7 & 1320.7 & 1216.8 & 929.6 \\
\hline 1995 & 71.7 & 403.3 & 304.3 & 248.4 & 877.0 & 3352.4 & 1859.3 & 1657.1 & 1141.0 \\
\hline 2000 & 111.3 & 478.8 & 296.4 & 255.1 & 1024.4 & 3471.5 & 2180.4 & 2227.2 & 1267.5 \\
\hline 2005 & 187.4 & & 324.1 & 255.0 & 932.5 & 3537.5 & 2840.9 & 2484.4 & 1318.1 \\
\hline 2007 & 233.5 & & & 260.3 & 1089.2 & 3583.4 & 3055.9 & 2595.1 & 1327.6 \\
\hline \multirow[t]{3}{*}{ 2007: China/country } & 1.00 & & & 0.90 & 0.21 & 0.07 & 0.08 & 0.09 & 0.18 \\
\hline & \multicolumn{9}{|c|}{ B. UNIDO Earnings Data } \\
\hline & \multicolumn{5}{|c|}{ Emerging markets } & \multicolumn{4}{|c|}{ Developed economies } \\
\hline Year & China & India & Indonesia & Malaysia & Thailand & Hong Kong & Japan & Korea & Singapore \\
\hline 1981 & 41.4 & 119.3 & 68.3 & 259.2 & & 825.2 & & 578.8 & 875.7 \\
\hline 1985 & 53.6 & 146.6 & 87.3 & 343.5 & 280.1 & 955.7 & 2695.5 & 733.1 & 1233.2 \\
\hline 1990 & 67.3 & 161.6 & 73.8 & 327.1 & 291.4 & 1267.7 & 2955.8 & 1233.0 & 1421.4 \\
\hline 1995 & 100.7 & 175.5 & 126.4 & 403.5 & 328.6 & 1429.4 & 3047.9 & 1819.7 & 1846.3 \\
\hline 2000 & 237.0 & 175.2 & 133.9 & 481.1 & 325.0 & 1524.4 & 3136.2 & 2030.9 & 2208.6 \\
\hline 2004 & 247.6 & 180.5 & & 615.6 & & & 3191.3 & & 2240.2 \\
\hline 2004: China/country & 1.00 & 1.37 & & 0.40 & & & 0.08 & & 0.11 \\
\hline
\end{tabular}

Data Source: ILO (2009), UNIDO (2007), Wu and Yue (2008) and authors' calculation. 
Data Appendix: Description of Data Sources and Adjustments

\section{Data for China}

The nominal Chinese wage data and CPI figures used in this paper are from three sources:

China Statistical Yearbooks (NBSa, various yeras), Comprehensive Statistical Data and

Materials on 55 Years of New China (NBSb, 2004) and the database of CEIC Data Company.

We use urban CPI and choose 2007 -- the latest year with available data -- as the base year, converting nominal wages into real terms for time series analysis. Provincial wages are deflated by provincial urban CPIs (except for Shanghai and Chongqing, where total provincial CPIs are used in their place), while wages by industry and wages by different ownership types are adjusted by national urban CPI, as industry and ownership type specific CPI data is not available.

Urban CPI instead of provincial CPI is used for two reasons: Firstly, it is more complete. Most provinces have urban CPI data from 1979 but more limited availability of provincial CPI, except for the prefecture-level municipalities of Chongqing and Shanghai, where we use provincial CPI instead, due to its greater historical availability. Secondly, urban CPI is more consistent with the definition of staff and workers, which does not include people employed in township enterprises. Urban CPI is missing for Chongqing from 1978 to 1983 and for Tibet from 1978 to 1988.

29 provinces are grouped into 7 regions following the international convention as the following. Bohai (Beijing, Tianjin, Shandong, Hebei), Southeast (Shanghai, Zhejiang, Guangdong, Jiangsu, Fujian), Northeast (Liaoning, Heilongjiang, Jilin), Central (Hunan, Anhui, Hubei, Henan, Jiangxi) Southwest (Chongqing, Yunnan, Sichuan, Guangxi, Hainan, 
Guizhou), and Northwest (Qinghai, Ningxia, Inner Mongolia, Shanxi, Xinjiang, Gansu, Shaanxi). Tibet is not grouped into any of the regions because it has a very short series of wage data and the sample size is very small. Regional wages are calculated as the weighted average of the provincial wages within that region, with the shares of staff and workers being used as weights. Provincial staff and workers’ wages are missing for Inner Mongolia (1979) and Chongqing (1979, 1981-84). Missing staff and workers numbers include: Inner Mongolia (1979), Hainan (1979), Chongqing (1979, 1981-84).

From 2003, the National Bureau of Statistics changed the coverage and definition of five industry sectors, and extended the original classification of 15 industry sectors to include 19. Matching is performed for the following five industry sectors between the old category and new category for the purpose of a complete time series data (new category in parenthesis): geological prospect and water conservancy (water conservancy, environment and public utility management), social services (residential service and other service), education, culture art, radio, film and TV (education), scientific research and polytechnic service (scientific research, technical service and geological), government party agencies and social organization (public management and social organization). The following four sectors were added in 2003, so our database contains only five years of data for these four sectors:

information transmission, computer service and software, accommodation and catering trade, leasing and commercial service, and culture, sport and recreation.

II. International Manufacturing Wages 
International manufacturing wages are from two sources: International Labor Organization (ILO) LABORSTA database at http://laborsta.ilo.org/ (ILO, 2009) and United Nations Industrial Development Organization (UNIDO, 2007).

For ILO data, earnings per month data are reported for most of our chosen economies except for Hong Kong and Thailand, where wage rate per day and wage rate per month are reported, respectively. Definitions of earnings and wage rate are different in the ILO documentation:

“The concept of earnings, as applied in wages statistics, relates to remuneration in cash and in kind paid to employees, as a rule at regular intervals, for time worked or work done together with remuneration for time not worked, such as for annual vacation, other paid leave or holidays. Earnings exclude employers' contributions in respect of their employees paid to social security and pension schemes and also the benefits received by employees under these schemes. Earnings also exclude severance and termination pay.”

“Wage rates should include basic wages, cost-of-living allowances and other guaranteed and regularly paid allowances, but exclude overtime payments, bonuses and gratuities, family allowances and other social security payments made by employers. Ex gratia payments in kind, supplementary to normal wage rates, are also excluded.”

Comparison between the above two definitions shows overtime payments are not included in the wage rate. Thus reported working hours for Hong Kong and Thailand are used to convert wage into earnings which take into account the overtime payment. Specifically, the calculation is as follows:

- Working hours per week is used to convert wage per day into earnings per month for 
Hong Kong: earnings per month $=($ wage per day $/ 8) \times$ working hours per week $\times 4.3$, where we assume that the daily working hours is 8 , and 4.3 weeks per month is calculated by dividing 52 weeks a year by 12 months.

- Working hours per month is used to convert wage per month into earnings per month for Thailand: Earnings per month $=[($ wage per month $) /(40 \times 4.3)] \times$ working hours per month, where we assume that the weekly working hours are 40 (8 hours per day and five days per week). Data on working hours are not complete for Thailand. For 1983-1995, hours of work per month are reported, and for 2000-2003 hours of work per week are reported, which are multiplied by 4.3 to get the monthly working hours. Missing values for hours of work are estimated as the following: for years after 2003, 2003 number is used; for years 1980-82, 1983 number is used; for years 1996-1999, the average of year 1995 and 2000 working hours is used. The reason we did not use a linear interpolation to estimate the missing working hours as we did in missing earnings data is that there is not a clearly increasing or decreasing trend of the working hours over the years.

Different from ILO data, where earnings per month in total manufacturing for each economy is directly reported, UNIDO reports total annual wage bills and numbers for employment for all sub-sectors in manufacturing for each country. Thus monthly manufacturing wages are derived by dividing the annual wages in all manufacturing sectors by the total number of employees in the manufacturing, and then the annual individual wages are divided by 12 to get the monthly wages. Definition of wage in UNIDO reads: "The 
estimates of wages and salaries include all payments in cash or in kind made to "employees" or "operatives," as the case may be, during the reference year in relation to work done for the establishment. The payments include: (a) direct wages and salaries; (b) remuneration for time not worked; (c) bonuses and gratuities; (d) housing allowances and family allowances paid directly by the employer; and (e) payments in kind. Excluded are the employers' contributions in respect of their employees paid to social security, pension and insurance schemes, as well as the benefits received by employees under these schemes and severance and termination pay.” This definition is comparable to the earnings in ILO.

Although China is not included in the original UNIDO dataset, we bring in a comparable series for China based on the work of $\mathrm{Wu}$ and Yue (2008) who have applied standard definitions of labor earnings comparable to those used by ILO and UNIDO. They have explained the details of their estimation methods.

Data on Japan require special adjustment. There are two different periods based on different coverage, though the industrial classifications of both periods are under ISIC-Revision 2. From 1979 to 1993, the data include family allowances and mid- and year end bonuses. However, this sample design was revised beginning in 1994. From 1994-2003, the data only covers private sector and establishments with 10 or more regular employees. It is from June of each year, and measures regular scheduled cash earnings. Thus there is a downward kink between the year of 1993 and 1994 due to the exclusion of the allowances and bonuses. In ILO data, two earnings are reported for the year of 1993 under two different coverage systems, giving us the ratio of bonuses among total wage. Assuming that the bonus ratio among total earnings stayed constant over the years, we adjusted wages after 1993 by 
multiplying the reported wage with 1 plus the value of the bonus ratio. However, UNIDO data has no such availability of two earnings for the same year under two different coverage systems. To try to standardize data after 1993 with the new definition, we constructed estimates of the average bonus percentage of total wage in the following way. We took the average annual growth rate from 1994 to 1996 and interpolated back to the start of data collection in 1985. Then, comparing these estimates of bonus-free wages with the given data, we constructed an average bonus percentage for those years. We finally use this percentage to standardize the bonus-exclusive data.

There are several missing wages in both ILO and UNIDO data; if the missing value is in the middle of two years with available data, a linear interpolation is used to estimate the wage, in order to keep the continuation of the data without affecting the overall trend. However, if the earnings are missing in the beginning or the ending years, no estimation is made. The country-year missing earnings estimated for ILO include: Philippines 2000 and 2002, Taiwan 2003, Thailand 1987 and 1988, Malaysia 1998 and 1999; and for UNIDO: Malaysia 1998, Thailand 1983, 1985, 1987, 1992, 1995, 1997 and 1999.

Both earnings and wages in ILO and UNIDO are in nominal local currency. After consolidating the earnings and wages for each individual country, we use country specific CPI (with 2007 as base year) to obtain the real wage in local currency over time and then use 2007 exchange rates to the U.S. dollar to standardize different currencies for cross-country comparison.

Though every effort has been made to make the earnings across economies comparable, it should be born in mind that the reported earnings per month from both ILO LABORSTA 
and UNIDO are represented by two revisions of International Standard Industrial

Classification of all Economic Activities (ISIC) database, know as Revision 2 and Revision

3. Different countries switch to the new standard of data collection at different times, and are from different surveys whose coverage may differ. Therefore, international comparison on earnings should be interpreted with caution.

III. List of data files available upon request

(a) Table A.1: Average Real Annual Wage of Staff and Workers by Ownership type (in 2007 yuan)

(b) Table A.2: Average Real Annual Provincial \& Regional Real Wage per Staff and Worker (in 2007 yuan) yuan)

(c) Table A.3: Average Real Annual Wage of Staff and Workers by Industry (in 2007

(d) Table A.4: Manufacturing Earnings per Month per Person from ILO (in 2007 USD)

(e) Table A.5: Manufacturing Earnings per Month per Person from UNIDO (in 2007 USD)

(f) Table A.6: Coverage of Data Surveys and the Time Periods under ISIC Rev-2 and ISIC Rev-3 